\title{
Tips for Teaching the "Service Design Thinking" to Students of Higher Education Institutions
}

\author{
Ivan Traina, Antonio Fracasso \\ Department of Education Studies, ALMA MATER STUDIORUM University of Bologna, Bologna, Italy \\ Email: ivan.traina@unibo.it, antonio.fracasso3@unibo.it
}

Received 28 July 2016; accepted 12 August 2016; published 16 August 2016

Copyright (C) 2016 by authors and OALib.

This work is licensed under the Creative Commons Attribution International License (CC BY).

http://creativecommons.org/licenses/by/4.0/

(c) (1) Open Access

\begin{abstract}
This paper sheds light on an experience realized in the framework of a workshop addressed to students of Higher Education Institutions having the topic as Service Design Thinking. It reports some advice for teaching this new concept based on some elements raised and those deserve to be shared with the growing community of professionals interested in this topic. The manuscript focuses mainly on practical aspects to take into consideration when organizing workshops addressed to these specific learners. It consists of three main sections, including a list of references of the literature inherent in the topic, practical suggestions and a discussion about the lesson learnt. This work is not an evidence-based research, but a collection of literature samples and practical feedback emerged. It is aimed at stimulating a wide confrontation on this concept in order to find practices that can help to allow the adoption of its main principles and the understanding of its implication when used to design services.
\end{abstract}

\section{Keywords}

Service Design Thinking, Teaching, Workshop, Experiment, Participatory Approaches

Subject Areas: Education

\section{Introduction}

This paper presents some advice for teaching the Service Design Thinking (SDT) to students of Higher Education Institutions (HEI).

It sheds light on a workshop addressed to this particular audience having the topic as SDT [1].

From this experience, some elements raised and we think they deserve to be shared with the growing community of professionals (such as academics, educators, caregivers, social scientists and policy makers) interested in 
to apply this innovative concept for the design and provision of services.

Despite that this experience has been realized in the context of education [2], the elements emerged are interesting and useful for the organization and implementation of workshops, training paths, academic lectures, etc.

When we talk about services, we use this term in a holistic sense including society, health, education, employment, leisure and support services that involve all the wide range of organizations (public, private, nonprofit) and actors that compose the current welfare state in many EU countries [3] [4].

In order to avoid any debate on "what is or not" the SDT, here some references are reported concerning this new concept.

The paper focuses mainly on some practical aspects to take into consideration when organizing workshops addressed to these specific learners.

The literature provided, as the experience realized, do not want to be exhaustive, but explanatory of an innovative concept for the definition of services.

Whereby, the paper consists of three main sections:

1) List of references concerning the literature inherent the topic.

2) Suggestions about the questions raised in the planning of the workshop and considered as useful starting points for the organization of teaching and learning activities. These questions focus on the following topics:

-How to present the SDT to students

-How to organize the tasks assigned to students

-How to capitalize the outputs realized by students

3) Final discussion about the lesson learnt.

This paper is not an evidence-based research, but a collection of literature samples and practical feedback emerged during the workshop addressed to higher education students and realized in the framework of the Social Educator degree, during academic years 2015-2016.

Therefore, it wishes to stimulate both a free debate and a wide confrontation on an innovative concept that for sure will require more investigation: such as finding practices that allow the adoption of the main principles of the concept of design service in an evolving society.

So we welcome any feedback that will be able to understand how to implement and exploit the transfer of such concept.

\section{The Current Literature}

Before presenting the experience carried out it is useful to provide a list of references in order to deepen the theory behind the concept of SDT.

Therefore, following are reported some samples from the current literature that can orientate to find more insight on the topic.

The narrative literature review was undertaken for the realization of the workshop due to the paucity of research about this concept. To locate literature relevant to the purpose of this review the databases PsycINFO, ERIC, Google Scholar, and ProQuest were searched from their earliest records to most recent. The search terms used were: service design, creative-divergent thinking, participation, cooperation as well as other search terms derived from design.

Manual searches of reference lists of relevant articles were conducted to identify further studies.

Outcomes of interest were those relating to the domains of the design, service delivery, participation and reallife. Table 1 report the literature by author, year and title.

\section{Framework of Reference}

The actions that should be put in to practice to teach the SDT need to be defined in the framework of precise pedagogical approaches, in order to avoid the elaboration of contents or strategies that are not theoretically founded and don't fit with the real learning needs.

For this reason, we have summarized some examples of innovative pedagogical approaches that can represent the framework of reference in case of teaching SDT.

As innovative concepts require the use of new approaches (including tools, strategies, assessment processes), also the definition of innovative services needs new insight about their design and implementation [5]. 
Table 1. Main sample of the literature by author, year and title.

\begin{tabular}{|c|c|}
\hline Author, year & Title \\
\hline Akama, Y., 2009 & $\begin{array}{l}\text { Warts-and-all: the real practice of service design. } \\
\text { First Nordic Conference on Service Design and Service Innovation. Oslo. Norway }\end{array}$ \\
\hline $\begin{array}{l}\text { Akiyama, Y., Shimomura, } \\
\text { Y, \& Arai, T., } 2009\end{array}$ & $\begin{array}{l}\text { A Method of Supporting Conflict Resolution for Designing Services. } \\
\text { 1st CIRP Industrial Product-Service Systems (IPS2) Conference (pp. 54-61). Cranfield, UK }\end{array}$ \\
\hline Bitner, M.J., 1992 & $\begin{array}{c}\text { Service scapes: The Impact of Physical Surroundings on Customers and Employees. } \\
\text { Journal of Marketing 56(2), pp. 56-71 }\end{array}$ \\
\hline $\begin{array}{l}\text { Blomkvist, J., } \\
\text { \& Holmlid, S. (2009). }\end{array}$ & $\begin{array}{l}\text { Examples in Service Design. First Nordic Conference on } \\
\text { Service Design and Service Innovation. Oslo, Norway }\end{array}$ \\
\hline $\begin{array}{l}\text { Burns, C., Cottam, } \\
\text { H., Vanstone, C., } \\
\text { \& Winhall, J., } 2006\end{array}$ & Transformation Design. London, UK: Design Council \\
\hline $\begin{array}{l}\text { Candi, M., } \\
\text { \& Saemundsson, R. J., } 2008\end{array}$ & $\begin{array}{l}\text { "How different? Comparing the use of design in service innovation in Nordic and } \\
\text { American new technology-based firms". Design Studies 29: pp 478-499 }\end{array}$ \\
\hline $\begin{array}{l}\text { Carr, V., Sangiorgi. } \\
\text { D., Buscher, M., Cooper, } \\
\text { R. \& Junginger, S., } 2009\end{array}$ & $\begin{array}{l}\text { Clinicians as service designer? Reflection on current transformation in the UK health service. } \\
\text { First Nordic Conference on Service Design and Service Innovation. Oslo Norway }\end{array}$ \\
\hline $\begin{array}{l}\text { Cautela, C., Rizzo, } \\
\text { F, \& Zur1o, F., } 2009\end{array}$ & $\begin{array}{l}\text { Service Design Logic: An approach based on the different service categories. Proceeding of the } \\
\text { International Association of Societies of Design Research, IASDR 2009. Seoul, Korea }\end{array}$ \\
\hline Clatworthy, S, 2009 & $\begin{array}{l}\text { Bridging the gap between brand strategy and customer experience. The target experienced tool. } \\
\text { First Nordic Conference on Service Design and Service Innovation. Oslo, Norway }\end{array}$ \\
\hline $\begin{array}{l}\text { Cooper, A. Reimann, } \\
\text { R., \& Dubberly, H., } 2003\end{array}$ & About Face 2.0: The Essentials of Interaction Design. Hoboken, NJ: John Wiley \& Sons, Inc. \\
\hline $\begin{array}{l}\text { Diana, C., Pacenti, E., } \\
\text { \& Tassi, R., } 2009\end{array}$ & $\begin{array}{l}\text { Visual tiles-Communication tools for (service) design. } \\
\text { First Nordic Conference on Service Design and Service Innovation. Oslo, Norway }\end{array}$ \\
\hline Evenson, S., 2005 & Designing for Service. Proceeding of DPPI. Eindhoven, Netherlands \\
\hline Frayling, C., 1993 & Research in Art and Design. Royal College of Art Research Papers, 1(1): pp. 1-5 \\
\hline $\begin{array}{l}\text { Gaver B., Dunne T., } \\
\text { Pacenti E., } 1999\end{array}$ & Design: Cultural Probes. In interaction 6(1): 21-29 \\
\hline Gloppen, J., 2009 & $\begin{array}{l}\text { Service Design Leadership. First Nordic Conference on } \\
\text { Service Design and Service Innovation. Oslo, Norway }\end{array}$ \\
\hline $\begin{array}{l}\text { Gong, M., Suteu, } \\
\text { I. M., \& Shen, J., } 2009\end{array}$ & $\begin{array}{l}\text { Chita 08: Collaborative Service and Mobile Communication: } \\
\text { A Service Design Workshop on Chinese Sustainable Lifestyles and Inter-Culture Experiences. } \\
\text { 8th European Academy of Design Conference, (pp. 174-179). Aberdeen, UK }\end{array}$ \\
\hline Han, Q., 2009 & $\begin{array}{l}\text { Managing Stakeholder Involvement in Service Design: Insights from British service designers. } \\
\text { First Nordic Conference on Service Design and Service Innovation. Oslo, Norway }\end{array}$ \\
\hline Holmlid, S., 2007 & $\begin{array}{l}\text { Interaction design and service design: Expanding a comparison of design disciplines. } \\
\text { Nordic Design Research Conference, NorDes 2007. Stockholm, Sweden }\end{array}$ \\
\hline $\begin{array}{l}\text { Kaario, P, VaajakaIlio, K., } \\
\text { Lehtinen, V., Kantola, V., } \\
\text { \& Kuikkaniemi, K., } 2009\end{array}$ & $\begin{array}{l}\text { Someone Else’s Shoes-Using Role-Playing Games in User-Centered Service Design. } \\
\text { First Nordic Conference on Service Design and Service Innovation. Oslo, Norway }\end{array}$ \\
\hline $\begin{array}{l}\text { Kim, Y. S., Wang, E., Lee. } \\
\text { Y. C., \& Cho, Y. C., } 2009\end{array}$ & $\begin{array}{l}\text { A Product-Service System Representation and Its Application in a Concept Design Scenario. } \\
\text { 1st CIRP Industrial Product-Service Systems (IPS2) } \\
\text { Conference. 1-2April } 2009 \text { (pp. 321-39). Cranfield, UK }\end{array}$ \\
\hline Kirnbell, L., 2009 & $\begin{array}{l}\text { Insights from Service Design Practice. 8th European Academy of Design Conference. } \\
\text { (pp. 249-253). Aberdeen, UK }\end{array}$ \\
\hline $\begin{array}{l}\text { Kimbell L. } \\
\text { \& Siedel, P., } 2008\end{array}$ & $\begin{array}{l}\text { Designing for Services-Multidisciplinary Perspectives: Proceedings from the Exploratory Project on } \\
\text { Designing for Services in Science and Technology-based Enterprises. Oxford. UK: Said Business School }\end{array}$ \\
\hline $\begin{array}{l}\text { Kronqvist, J., } \\
\text { \& Korhonen, S.-M., } 2008\end{array}$ & $\begin{array}{l}\text { Co-Designing Sustainable Solutions_-Combining Service Design and Change Laboratory. } \\
\text { First Nordic Conference on Service Design and Service Innovation. Oslo, Norway }\end{array}$ \\
\hline $\begin{array}{l}\text { Lee, M. K., } \\
\text { \& Forlizzi, J., } 2009\end{array}$ & $\begin{array}{l}\text { Designing Adaptive Robotic Services. Proceedings of the International } \\
\text { Association of Societies of Design Research, IASDP 2009. Seoul, Korea }\end{array}$ \\
\hline
\end{tabular}




\section{Continued}

Maffei, S., Mager, B., \& Sangiorgi, D., 2005

Mager, B., 2004

Manzini, E.,1993

Miettinen S., \& Koivisto, M., 2009

Morelli, N., 2002

Morelli, N., 2003

Morelli, N., 2009

Pacenti, E., 1998

Pacenti, E., \& Sangiorgi, D., 2010

Parker, S.,

\& Heapy, J.,2006

Penin, L.,

\& Tonkinwise, C., 2009

Pinhanez, C., 2009

Popovic, V., Kraal, B. J., \& Kirk, P. J., 2009

Raijmakers, B., van Dijk, G Lee. Y. \& Williams, S. A., 2009

Sangiorgi, D., 2004

Segelstrom, F., 2009

Segelstrom, F. Raijmakers,

B. \& Homlid S., 2009

Segelstrom, F, \& Holmlid, S. (2009).

Shostack, L., 1982

Shostack, L.,1984

Singleton, B., 2009

Sparagen, S. L.

\& Chan. C., 2008

Stickdorn, M.

\& Zehrer, A., 2009

Wreiner, T., Martensson,

I., Arnell, O.,

Park Gonzalez,

N., Holmlid, S.,

\& Segelstrom, F., 2009
Innovation through Service Design. From Research and Theory to a

Network of Practice. A Users’ Driven Perspective. Joining Forces. Helsinki, Finland

Service design: A review. Cologne, Germany: KISD

Il Design dei Servizi. La progettazione del prodotto-servizio. Design Management (7)

Design Services with Innovative Methods

Designing Product/Service Systems: A Methodological Exploration. Design Issues, 18(3): pp. 3-17

Product-service systems, a perspective shift for designers: A case study: the design of a telecentre. Design Studies24: pp. 73-99

Service as Value co-production: reframing the service design process. Journal of Manufacturing Technology and Management, 20 (5), 568-590

Il proget to dell'interazione nei servizi. Un contributo al tema della progettazione dei servizi. (Vol. PhD thesis in Industrial Design). Milan, Italy: Politecnico di Milano.

Service Design research pioneers: An overview of Service

Design research developed in Italy since the'90s. Design Research Journal 2010 (1), pp. 26-33

The Journey to the Interface. London, UK: Demos

The Politics and Theatre of Service Design. Proceedings of the International

Association of Societies of Design Research, IASDR 2009. Seoul, Korea

Services as Customer-Intensive Systems. Design Issues, 25 (2) pp.3-13

Passenger experience in an airport: an activity-centred approach. Proceeding of the International Association of Societies of Design Research, IASDR 2009. Seoul, Korea

Designing Emphatic Conversations for Inclusive Design Facilitation. Include 2009. London, UK

Il Design dei servizi come Design dei Sistemi di Attività. La Teoria dell’
Attività applicata all a progettazione dei servizi.

(Vol. PhD in Industrial Design). Milan, Italy: Politecnico di Milano

Communicating through Visualizations: Service Designers on Visualizing User Research. First Nordic Conference on Service Design and Service Innovation. Oslo, Norway

Thinking and doing ethnography in Service Design.

In Proceeding of the International Association of Societies of Design Research, IASDR 20009. Seoul, Korea

Visualization and tools for research: Service designer on visualizations. Nordic design Research Conference, NorDes 2009. Oslo, Norway

How to Design a Service. European Journal of Marketing (161), 49-63

Design Service that Deliver. Harvard Business Review, 62(1), pp. 133-139

Services Design in New Territories. Proceedings of the International Association of Societies of Design Research, IASDR 2009. Seoul, Korea

Service Blueprinting: When Customer Satisfaction Numbers are not enough. International DMI Education Conference. Cergy-Pointose, France

Innovation in Tourism. First Nordic Conference on Service Design and Service Innovation. Oslo, Norway

Exploring Service Blueprints for Multiple Actors: A Case Study of Car parking Service.

First Nordic Conference on Service Design and Service Innovation. Oslo, Norway 
In Table 2 some samples are reported.

If we start from choosing one or more of these approaches, it is possible to define a set of actions, methods, tools and processes based on an effective pedagogical approach representing the frame of reference. We have reported these four models because we think they can fit better with the features of the SDT and requirement of involvement and participation - two essential elements to build experiences based on real-life needs, especially when planning the use of a service.

It requires a certain effort to establish new way to transmit contents, but it is necessary if we want to enhance student's capability—capacity and ability [12]— to think in a different way.

In other words, we have to push towards a divergent way of thinking [13], instead of a classical convergent way [14].

It means to foster the finding of innovative solutions to the emerging needs, looking towards a more flexible approach to face the current problems and needs related to the provision of services.

\subsection{How to Present the Service Design Thinking}

The SDT can represent for the students of HEI an instrument of knowledge and interaction with the world and society.

It is a concept that allows to be aware of the outsourcing of the society and its ways to build the experiences of the people who live in it. It means, for instance, how to design and organize services delivery and provision.

Moreover, it can enable to move from a phase of passive observation (first point of view) to an active construction of the services integrated into the user world (second point of view).

The acquisition of this dual vision (both of the observer and of the designer) represents the first step for moving towards the SDT. To foster the knowledge and the identification of the needs and services provision that surround the student allows him/her to a critical vision.

$\mathrm{He} / \mathrm{she}$ is no longer a passive actor of flows designed by others, but becomes active agent [15] within the service, able to understand their straightness and weaknesses. This has also an impact in term of active citizenship [16].

In a society strongly outsourced, students quickly become aware that most of their daily actions are part of the flow of services (e.g. to buy a product, to pay bills, to study, to find a job, to receive health care, or social support).

For each of these actions, he/she becomes aware of being a player in the big game of the services [17].

Table 2. Sample of pedagogical approaches that fit better with SDT.

\begin{tabular}{|c|c|}
\hline Approach & Features \\
\hline $\begin{array}{l}\text { Participatory } \\
\text { Approach }\end{array}$ & $\begin{array}{c}\text { It is an approach in which everyone who has a stake in the intervention has a voice. } \\
\text { Staff of the organization that will run it, members of the target population, } \\
\text { community officials, interested citizens, and people from involved agencies, } \\
\text { schools, and other institutions should be invited to contribute [6] }\end{array}$ \\
\hline $\begin{array}{l}\text { Cooperative } \\
\text { Learning }\end{array}$ & $\begin{array}{l}\text { It is an approach which aims to organize classroom activities into academic and social learning experiences. } \\
\text { Unlike individual learning, which can be competitive in nature, students learning cooperatively } \\
\text { can capitalize on one another's resources and skills. Everyone succeeds when the group succeeds [7] }\end{array}$ \\
\hline $\begin{array}{l}\text { Process Oriented } \\
\quad \text { Guided } \\
\text { Inquiry Lessons }\end{array}$ & $\begin{array}{l}\text { It is an approach based on a learning strategy that has both a constructivist and social component, } \\
\text { it focuses on using the real life experiences of the learner to create knowledge and considers } \\
\text { how students relates to the environment where they are taught [8] }\end{array}$ \\
\hline Reality Pedagogy & $\begin{array}{l}\text { It is an approach where the fundamental premise is that students } \\
\text { are the experts on how to teach, and students are the experts on content. } \\
\text { So, there has to be an exchange of expertise between students and teacher [9] }\end{array}$ \\
\hline Social Learning & $\begin{array}{l}\text { It is an approach that tries to developing cultures and environments for learning that harness the } \\
\text { emancipatory power of spaces and interactions outside the formal curriculum, particularly } \\
\text { through the use of new technologies and co-curricular activities [10] }\end{array}$ \\
\hline $\begin{array}{c}\text { Project } \\
\text { Based Learning }\end{array}$ & $\begin{array}{l}\text { It is an approach which focuses primarily on having students engage in explorations of real-world } \\
\text { problems and challenges. Students learn about a subject by working for an extended period of time } \\
\text { to investigate and respond to a complex question, challenge, or problem [11] }\end{array}$ \\
\hline
\end{tabular}


Therefore, through the SDT he/she can understand that "Services" are something that belong to the lives of everyone (in positive or negative way).

For some people this "awakening" represents often both an opportunity and a sort of trauma or amazing wonder, because to think that a large percentage of daily actions are the result of a good or bad design, it is like to feel as a puppet.

In this awaking, we found an interesting element of SDT. Secondly, it leads to show the "wires" that underlie the actions, and it represents the second step towards the SDT and the comprehension of what delivered and the user experience.

The understanding of the wires behind the design of a service is important for planning, implementing and delivering. Two reflections raised on this specific issue:

1. The experience design service

2. The outsourcing experience of the service through its reproducibility

These two reflections should be contextualized (e.g. in the service provision about education, heath, employment, etc.) and experienced by the group of students who will work in its design.

The main objective is to place students in the same designer's point of view, and then let them to experiment a sort of oriented creativity [18].

In this way, the elaboration of the service flow require a specific attention of user's experience that implies the understanding and the managing of the concepts of reproducible and serial user experience.

So, to stimulate a dual vision (and thus not having longer merely a passive way of thinking to services), and to understand what lies behind service's design, represent the prerequisite for introducing and presenting the SDT.

Other requirement is the involvement and participation of other actors (e.g. public-private services representative, local authorities, social agencies, etc.) interested in the provision, delivery and use of services. In case it is difficult to involve such actors, in accordance with them, and in order to facilitate the understanding of these reflections, can be useful to organize a preliminary visit to the service selected and to interview some users before and after the provision of service.

We recommend to use a short list of questions, better if these are based on Yes/No or a Likert scale [19] answers, collecting information, perceptions, attitudes, needs and ideas from the users in order to start to plan the reproducibility of the service and the experience users live when accessing to it.

\subsection{How to Organize the Tasks for Students}

For the organization of the tasks to be assigned to students, we recommend to define a precise pathway [20] mastering the main steps. Overall, because using one of the frameworks suggested in the previous paragraph the process of learning can be more or less structured or more open or closed to external influences [21]. Teachers need to take care of this and support students. Therefore, we have organized the tasks following a pathway made by four phases that students should adopt, once divided in small groups of 4 - 6 persons:

Phase 1) Explore

Selection of one or more techniques appropriate to the subject area. Through the chosen techniques, make an exploration of the needs addressed by the service.

Phase 2) Create

Elaboration of the service flow in all its aspects, considering the feedback collected through the involvement of services delivery (e.g. operators, designers, etc.) or the data from the interview.

Phase 3) Implement

Test or simulate the service using the flow designed and feedback collected.

Phase 4) Reflect

The data collected have to be analyzed and indexed in order to determine the level of performance, level of satisfaction, level of accessibility, etc.

The review of data allow an iterative prospective that facilitate the re-exploration or the re-designing of the service on the base of what emerged and a continuous improving.

For each phase, we have defined some methods that can be used in different contexts for the elaboration of services (e.g. services for supporting persons in tourism, employment, education, health care, leisure, etc.).

Some examples of contexts and methods used are reported in the Table 3.

All the tasks that will be assigned to students should be organized leaving students the opportunity for creating or selecting the methods that better fit with the service's aims, needs and students background. 
Table 3. Examples of contexts and methods used.

\begin{tabular}{|c|c|c|}
\hline \multirow{2}{*}{ Phase } & \multicolumn{2}{|l|}{ Methods } \\
\hline & Methods applied to on-line context & Methods applied to social context \\
\hline Explore & $\begin{array}{l}\text { The tool "Personas" allows building a prototype of single user. } \\
\text { The prototype represents the desires of users }\end{array}$ & $\begin{array}{l}\text { The tool "Ethnographic research" allows } \\
\text { the identification of social groups in terms } \\
\text { of needs of users and relative service }\end{array}$ \\
\hline Create & $\begin{array}{l}\text { The instrument "Cognitive walkthrough" allows the Personas to } \\
\text { walk into the service and define each stage of the on-line service }\end{array}$ & $\begin{array}{l}\text { The instruments of "Stakeholder Map" and } \\
\text { "Touch Points Map" allows students to elaborate } \\
\text { and develop more complex conceptions/attitudes } \\
\text { of the users respect the service hypothesized }\end{array}$ \\
\hline Implement & $\begin{array}{l}\text { The definition of "Indexes and Indicators" } \\
\text { for the simulation of the hypothesized service }\end{array}$ & $\begin{array}{l}\text { The definition of "Indexes and Indicators" } \\
\text { for the analysis of the hypothesized service }\end{array}$ \\
\hline Reflect & \multicolumn{2}{|c|}{$\begin{array}{l}\text { The use of the Indexes and Indicators already defined represent the rings of feedback and dynamic analysis of data. } \\
\text { Providing possible scenarios where to rethink the service if it doesn't fit with user expectations/needs/desires }\end{array}$} \\
\hline
\end{tabular}

\subsection{How to Capitalize the Outputs Achieved}

During the development of the experience, students have experimented a creativity-oriented process and need-based analysis [22].

They have also experienced forms of empathy with users [23] through interview, collection of data focusing on their needs, adoption of methods such as personas, mental map, touch point map, target segmentation, etc.

Finally, students have designed a service on the base of user real needs and context resources.

In order to capitalize the outputs achieved it is fundamental to have the opportunity to transform this into practice and testing what has been created within a precise context.

As previously highlighted, the collaboration with public-private institutions, local authorities and volunteer associations is important.

The core of all the process is the attempt to realize what designed including the possibility of recursion, re-thinking and a re-design the service.

The major effort will consist precisely in the establishment of a strict collaboration and an effective participation with service providers that can assure the possibility to develop and test something new, created by student (often unaware-user) and designed with the suggestions of operators and real-users.

This can be useful also to create a link between what studied in HEI and the real-life, outside the places where to teach and learn approaches, methods and tools to design future scenarios.

SDT allow organizing classroom activities into academic and social learning experiences, where students learn cooperatively and can capitalize on one another's resources and skills. Furthermore, the role of teachers changes from giving information to facilitating students' learning.

Moreover, for capitalizing the outputs achieved it was useful to organize a restore activity (e.g. creation of a dedicated database).

Every group of students has registered a blog aimed to keep track of the design process respecting the two precise principles of SDT: seriality and iteration.

These principles have introduced the students to the fact that although they cannot develop or test what they have created, the hypothesized service has the opportunity to be experimented (even if in a virtual context) verifying its meta-features (as the methodology applied) through empirical tests to assess the effectiveness, the usability, the indexes and indicators defined in the design process.

In other words, the seriality is proposed to students as a means of re-production of the service creation process. The iteration is proposed as a means of re-vision of the service creation process.

\section{Lesson Learnt}

In the final part of the experience, the students have had the opportunity to compare their works, that is the design processes of services in order to identify and analyze the features in the application of the selected methods.

The lesson learned is that the SDT is not a unique method and that there is a meta-design process through which to organize and structure the service. 
The SDT captures both skill inherent the methods and meta-skill to contextualize and organize processes. This is based on a learning strategy that has both a constructivist and social component, making a focus on the real life experiences of users and learners to create knowledge and considers how they relate to the environment where they are taught.

SDT focuses primarily on having students engage in explorations of real-world problems and challenges. They learn about a subject by working for an extended period of time to investigate and respond to a complex question, challenge, or problem.

The documentation of the service creation process allowed the comparison of what was designed by the different groups of students involved.

The comparison showed that different methods were applied to different areas of concern and it led to different design processes.

Therefore, method and meta-design process are deeply connected with the area of concern where the service is being developed and the type of provision that service is intended to provide.

In conclusion, through this experience students have developed critical skills respect to the services where they will operate. In addition, as future operators, they will be more aware and able to have a constructive and participatory approach in the design of services.

\section{Conclusions}

The research allowed experiencing this innovative concept within academic lectures, leading to the creation of hypothetic services on the base of students' input, despite that they will not be trained as designers but as operators.

From this research it is shown that the future role of students that will operate in the services does not limit their creative capacity, but represents a starting point to develop new insights and ideas.

Therefore, it represents the seed for the growing practice of differentiation and optimization of the service. In other words, it is a useful way for ensuring its quality and continuous adaptation to users' needs and desires.

Besides, it has also allowed students to raise awareness of being part of larger design services where they will operate.

For this reason, we stress the importance to establish a sort of "pool" or "experimental environment" for service design, able to involve and interface with public and private services in order to put in practice what was designed for users.

\section{References}

[1] Stickdorn, M., Schneider, J., Andrews, K. and Lawrence, A. (2011) This Is Service Design Thinking: Basics, Tools, Cases. Wiley, Hoboken.

[2] Department of Education Studies “G.M.Bertin”-Alma Mater Studiorum University of Bologna. http://www.edu.unibo.it/en

[3] Esping-Andersen, G. (2002) Why We Need a New Welfare State. OUP, Oxford. http://dx.doi.org/10.1093/0199256438.001.0001

[4] Anttonen, A. and Sipilä, J. (1996) European Social Care Services: Is It Possible to Identify Models? Journal of European Social Policy, 6, 87-100. http://dx.doi.org/10.1177/095892879600600201

[5] Bean, J.C. (2001) Engaging Ideas: The Professor's Guide to Integrating Writing, Critical Thinking, and Active Learning in the Classroom. Jossey-Bass, San Francisco, CA.

[6] UNICEF (2014) Participatory Approaches. Methodological Briefs. Impact Evaluation No. 5.

[7] Ross, J. and Smythe, E. (1995) Differentiating Cooperative Learning to Meet the Needs of Gifted Learners: A Case for Transformational Leadership. Journal for the Education of the Gifted, 19, 63-82. http://dx.doi.org/10.1177/016235329501900105

[8] Moog, R.S. and Spencer, J.N., Eds. (2008) POGIL: Process Oriented Guided Inquiry Learning. ACS Symposium Series 994, American Chemical Society, Washington DC.

[9] Emdin, C. (2012) Reality Pedagogy and Urban Science Education: Towards a Comprehensive Understanding of the Urban Science Classroom. In: Second International Handbook of Science Education, Springer, The Netherlands, 59-68. http://dx.doi.org/10.1177/016235329501900105

[10] Ryan, A. and Tilbury, D. (2013) Flexible Pedagogies: New Pedagogical Ideas. Higher Education Academy, York. 
[11] Solomon, G. (2003) Project-Based Learning: A Primer. Technology and Learning-Dayton, 23, 20.

[12] Helfat, C.E. and Peteraf, M.A. (2003) The Dynamic Resource-Based View: Capability Lifecycles. Strategic Management Journal, 24, 997-1010. http://dx.doi.org/10.1002/smj.332

[13] McCrae, R.R. (1987) Creativity, Divergent Thinking, and Openness to Experience. Journal of Personality and Social Psychology, 52, 1258-1265. http://dx.doi.org/10.1037/0022-3514.52.6.1258

[14] Cropley, A. (2006) In Praise of Convergent Thinking. Creativity Research Journal, 18, 391-404. http://dx.doi.org/10.1207/s15326934crj1803_13

[15] Levin, B. (1994) Putting Students at the Center. Phi Delta Kappan, 75, 758-760.

[16] Lawson, H. (2001) Active Citizenship in Schools and the Community. Curriculum Journal, 12, 163-178. http://dx.doi.org/10.1080/09585170122413

[17] Lizzio, A., Wilson, K. and Simons, R. (2002) University Students' Perceptions of the Learning Environment and Academic Outcomes: Implications for Theory and Practice. Studies in Higher Education, 27, 27-52. http://dx.doi.org/10.1080/03075070120099359

[18] Baer, J. (2014) Creativity and Divergent Thinking: A Task-Specific Approach. Psychology Press, London.

[19] Allen, I.E. and Seaman, C.A. (2007) Likert Scales and Data Analyses. Quality Progress, 40, 64-65.

[20] Ambrose, S.A., Bridges, M.W., DiPietro, M., Lovett, M.C. and Norman, M.K. (2010) How Learning Works: Seven Research-Based Principles for Smart Teaching. John Wiley \& Sons, Hoboken.

[21] Hall, T. (2002) Differentiated Instruction. National Center, Wakefield.

[22] Lengnick-Hall, C.A. and Sanders, M.M. (1997) Designing Effective Learning Systems for Management Education: Student Roles, Requisite Variety, and Practicing What We Teach. Academy of Management Journal, 40, 1334-1368. http://dx.doi.org/10.2307/257036

[23] Wan, A.T. (2015) How Can Learners Learn from Experience? A Case Study in Blended Learning at Higher Education. International Journal of Information and Education Technology, 5, 615-619. http://dx.doi.org/10.7763/IJIET.2015.V5.578

\section{Submit or recommend next manuscript to OALib Journal and we will provide best service for you:}

- Publication frequency: Monthly

- 9 subject areas of science, technology and medicine

- Fair and rigorous peer-review system

- Fast publication process

- Article promotion in various social networking sites (LinkedIn, Facebook, Twitter, etc.)

- Maximum dissemination of your research work

Submit Your Paper Online: Click Here to Submit

Contact Us: service@oalib.com 